\title{
Analysis on the Professional Title Reform of Chinese Local Universities in New Era
}

\author{
Liwen Zeng \\ Human Resource Department \\ Guangdong University of Finance \& Economics \\ Guangzhou, P.R.China \\ 347761869@qq.com
}

\author{
Hua Yin ${ }^{*}$ \\ School of Information \\ Guangdong University of Finance \& Economics \\ Guangzhou, P.R. China \\ yinhua@gdufe.edu.cn
}

\begin{abstract}
China's social development has entered a new era. The main idea of "Some opinions on deepening to streamline government functions and administration, delegate powers while improving regulation for highereducation " is consis tent with the spirit of the Nine teenth National Congress in China. Guided by these opinions, the reform of professional titles in colleges and universities has got some achievements. But there is still a certain distance to realize the ultimate goal of the reform. The classification index system of professional titles is relatively simple, the supervision and execution is insufficient, and the appointment is not perfect. This paper analyzes above three problems, discusses the reform of professional titles from three aspects:(1)Formulating scientific classification review index system;(2)Clarifying the supervision procedure and different hierarchy's responsibilities;(3)Establishing the position duties and assessing strictly. And it takes Guangdong University of Finance and Economics as an example to show their reforms. The discussion provides a practical way to strengthen the reform of professional titles of $C$ hinese local universities in the new era.
\end{abstract}

Keywords-New Era; Professional Title Reform; Classification; Local Universities

\section{INTRODUCTION}

In 2017, China's Ministry of Education issued a document 'Some opinions on deepening to streamline government functions and administration, delegate powers while improving regulation for higher education(hereinafter referred to as the 'Opinions')'[1]. This document aims to further decentralization of power to local universities and ease the burden on universities. 'Opinions' puts forward to reform the professional title evaluation mechanism of higher education, and to put the power of professional title assessment of teachers in university to universities themselves. The professional title reform becomes a hot spot in current educational field.

In the $19^{\text {th }}$ National Congress of the Communist Party of China, President $\mathrm{Xi}$ announces that socialism with Chinese characteristics enters new era. In new era, the soul of President Xi's socialism thought with Chinese characteristics is "the affinity to the people", which is also the essence of universes in a socialist country [2]. It promotes new requirements for the professional title reform. Therefore, analyzing the problems after delegating the power in professional title reform and discussing how to solve these problems are valuable to promote

This work was supported by the Project of Educational commission of Guangdong province of China (no.2017GXJK053) the development of universities and boost the teachers' happiness level.

We firstly analyze the state-art of the professional title reform in new era, then point out some problems. At last, we discuss the solutions to these problems from the point of view of the mechanism reform. Our results will bring new perspectives to china's local universities. They can adopt our suggestions when they create their own regulations.

\section{RELATED WORK}

\section{A. China's Professional Title System In the University}

In professional title system, the review standard is a very important part. In [3], Wang pointed out that the review standard should consider teacher's comprehensive abilities. So it suggested making the index from the aspects of teaching, research and social service. In [4], Huang systematically analyzed the new problems based on the survey of china's professional title statement in 2013 and did a macroscopically study of the professional title reform road.

The review procedure is another important part, which determines the fairness and objectiveness of the review results. In [5], Zhu provided some detailed measurements aiming at the problems of the review procedure. In [6], Yu hold that less effective supervision and management lead to the unfairness of the review results. And they suggested that it should create comprehensive supervision mechanism and improve the management to guide fair professional title system.

In [7], Dong considered the professional title reform from the aspect of the balance between academic power and executive power. It is better to improve the status of academic power for obtaining the academic-administrative balance. These will be helpful to design reasonable professional title review regulations

\section{B. China's Professional Title Classification Review Mechanism In the University}

In recent years, Classification management has becoming a trend in the higher education professional title reform. The essence of classification management in professional title is to set the positions by their classifications and create different review standards to get the diversity vocational developments. 
Now, There is no a unified definition about higher education teacher professional title classification review in china. After analyzing the measurements which would promote the professional title reform, in [8], Yang put forward that classification management was a basic direction of china's professional title reform. The reform should obey with the law of teacher's career development. And it is a very important step to create a sound professional title classification management system. In [9], Chen took the Jiangsu Province as an example, and tried to solve the professional title review problems in Independent Colleges, which put more focus on research, less on teaching. In [10], Huang discussed how to scientifically create higher education teacher's performance evaluation index system by qualitative analysis methods. Yin ranked the teachers who were reviewed by the multi attributes decisionmaking methods in the military school [11]. But this method was too theorical to difficult to explain.

\section{Professional Title Classification Review Mechanism In the foreign countries}

In the primary western developed countries, the management of higher education is classified two types: separation of powers and centralization of powers. Countries represented by America and England belong to the first type. While countries like German and Japan, which is similar to china, belong to the second one. The character of the first one is the autonomy. On the other hand, the character of the second one is always controlled by the government.

It takes a long time to regulate the professional title classification review of the higher education teacher in America. Currently, America's review standard emphasis on “teacher's personality", which can be represented by diversity teaching, research and service workloads. It means that their review standard can be adjusted according to different person. In England, they always do the professional title review from the three aspects of research, teaching and management. They focus on the teacher' career development [12].

SusanK and Amy choose ten teachers in an America's research university as the research objects to find and conclude the detailed problems faced in the process of being a professor by a qualitative analysis method. They found that the most focused problems include lack of the clear promoting procedure, the sexual imbalance in professor numbers, and the sexual imbalance in the time of being promoted a professor [13].

In the university of Queensland, they especially pay attention to create the incentive system and evaluation mechanism for the teaching-oriented teachers. In their working report, they emphasis that it is the same procedure for the teaching-oriented teacher, research-oriented teacher and teaching and research teacher. But the standards are different. Teachers can chose as any type according to their achievements.

\section{Problems In Current Professional Title MECHANISM}

From the state-art of professional title reform, we find that there are fewer researches in new era. How to streamline the administration? How to delegate the power? And How to improve the service? There are some open problems about the professional title reform in new era. We will analyze three important problems.

\section{A. Inflexible professional title review index system}

The professional title reform has endured a couple of phrases from the exploration period in 1977 to the current "streamline the administration, delegate the power and improve the service" reform. In the exploration period, the administrative department formulated the unified management methods, which mainly measured the academic abilities of teachers by the research achievements. The rigid research conditions limited the teachers who were good at teaching. The existed professional title review index system emphasizes on academic ability, research achievement and activities, not on ideology and morality, teaching skills and social services.

From 2011, Higher education in China entered into the pattern of intensive development, which was led by the lower qualities of students and no enough high-qualified teachers. Not only considering the single research conditions, but also using the same review standard in the different universities is very inflexible. It is not beneficial to find their developing way in the different universities.

In 2017, “Opinions” brought new reforms to professional title. Different types of universities begun to formulate their own professional title review index system. This is also the internal requirements of the new era for the development of colleges and universities in line with the needs of the people and cultivating better talented students who serve the social and economic development of the new era. For further running the "Opinions" in the new era, professional title reform still has a long way.

\section{B. Deficient enforcement of supervision}

For a long time, the government departments are the makers of the professional title policies and the leader of the professional title evaluation. The local colleges and universities have always been the executors of the policies. They recommend the qualified applicants according to the unified evaluation methods formulated by the administrative departments, and then report to the education department to review. Finally, the review results were examined and approved by the office of human resources and social security.

In a new era, when the professional title review power is delegated to colleges and universities. The role of the various government administrative departments, colleges and universities has changed radically. The government department has transformed from the leader to the supervisor. Colleges and universities is no longer the executor of the professional title policies, but the formulator, the leader and the organizer of the professional title system. But all these related departments are still adapting to their roles for the unclear duties and responsibilities.

After delegated the power, the government department should mainly focus on the supervision and providing better services, not manage the professional title review. The 
administrative departments in colleges and universities should mainly focus on the review organization, not interfering in the fairness of professional title review. There are still some problems for the deficient enforcement of supervision. People who work in the administrative department utilize the power to influence the review index formulation, or interfere in the procedure of professional title review for their private reasons. For example, they may choose some review experts who are benefit for the certain person who want to pass the professional title review.

\section{Lack of sound appointment and evaluation mechanism}

The main point in the reform from "Opinions" is the combination of professional title review and post appointment. If you have the post, then you can do the professional title review, and then give the post appointment. Otherwise, it should not begin the professional title review. This combination aims at combining the talent selection with the requirements of the school development, finally achieving to make the best use of the talents who will most effectively serve for the school development. Therefore, in addition to scientific professional title review system, the necessary supervision, it should correspond with the incentive and assessment mechanism after the candidates pass the title review. Formulating clear position duties, strictly assessing by the duties and completing the management mechanism can achieve maximum efficiency of human resources.

However, reality is not as it is designed. The combination is not executed well. Some teachers have lost their internal motivation after obtaining a higher title. Because there are no detailed position duties and requirements. If they have got the higher title, they can reserve it forever. Currently, most of local colleges and universities have not formulated the corresponding position duties and responsibilities and been lack of the following position assessment.

Even though there are some position duties, the assessment always just take a form for the incomplete management system. This violates the purpose of reform, and is not benefit to the development of schools. It also affects the development of teachers' career.

\section{Discussion Of The Main Professional Title Reform In CHINESE LOCAL UNIVERSITY}

The professional title reform in Colleges and Universities includes many aspects. The construction of evaluation index system, the establishment of evaluation organization, the evaluation procedure and the supervision mechanism are all important contents of the reform. The evaluation index system, the supervision mechanism and the post-evaluation appointment management mechanism are an organic cycle system, which can be realized only when they are integrated. Constructing a scientific classification review index system is the embodiment of autonomy of colleges and universities, the supervision mechanism is the guarantee for the smooth progress of reform, and the management mechanism after appointment is not only the test of reform results but also the source of follow-up power. Combining with the achievements of the title reform of Guangdong University of Finance and
Economics and some existing problems, we discuss some solutions from following three aspects.

\section{A. Formulating scientific classification review index system}

In China, we have about 3000 colleges and universities, which include comprehensive high-level Universities, The local colleges and Universities served for the local economic development and the independent colleges and private universities funded by the private capitals. Various colleges and universities have different conditions. According to the orientation of each university, it is helpful for promoting the strength of universities and boosting the rapid development of universities to formulate characteristic classification review index system. We analyze the characters of different types of colleges and universities, at the same time, the corresponding suggestions about their professional title review system in the following table.

TABLE I. CLASSIFICATION INDEX SYSTEM SUGGESTIONS BY TYPES

\begin{tabular}{|c|c|c|}
\hline University Type & $\begin{array}{c}\text { Characteristics of } \\
\text { Universities }\end{array}$ & $\begin{array}{c}\text { Characteristics of Title } \\
\text { review index system }\end{array}$ \\
\hline $\begin{array}{c}\text { comprehensive } \\
\text { high-level } \\
\text { Universities }\end{array}$ & $\begin{array}{c}\text { Comprehensive } \\
\text { research university }\end{array}$ & $\begin{array}{c}\text { The index system is mainly } \\
\text { based on scientific research } \\
\text { conditions. }\end{array}$ \\
\hline $\begin{array}{c}\text { The local colleges } \\
\text { and Universities }\end{array}$ & $\begin{array}{c}\text { Application-oriented } \\
\text { Universities to serve } \\
\text { the local economic } \\
\text { development }\end{array}$ & $\begin{array}{c}\text { The index system is based } \\
\text { on res earch and application } \\
\text { oriented. }\end{array}$ \\
\hline $\begin{array}{c}\text { Focus on training } \\
\text { practical talents } \\
\text { colleges and } \\
\text { private universities }\end{array}$ & $\begin{array}{c}\text { urgently needed by the } \\
\text { society }\end{array}$ & $\begin{array}{c}\text { The index system is mainly } \\
\text { based on the effectiveness } \\
\text { of personnel training and } \\
\text { has great dynamic character }\end{array}$ \\
\hline
\end{tabular}

Taking the Guangdong University of Finance and economics (GDUFE) as an example, a local university of Finance and economics. According to the spirit of the guidance documents, the title in GDUFE is divided into four series: teaching, research, experiment and library.

The teaching series is divided into teaching based, teaching-research based. All types are divided into nature science and Humanities and Social Sciences. Considering the characteristics of the subject and the work content, GDUFE has set up specific evaluation indexes for sports, arts and the ideological and political education, such as taking the award of guiding students to participate in the contest as the evaluation conditions. At the same time, GDUFE has formulated corresponding teaching conditions oriented to school development.

This is an effective exploration of building a scientific classification and evaluation index system. Now the first round of the title evaluation of the school has been completed, but some of the evaluation indexes are still not scientific. For example, the conversion of scientific research achievements and the setting of teaching conditions still need to be perfected.

\section{B. Clarifying the supervision procedure and different hierarchies responsibilities}

In October 2017, the Ministry of education combined with and the Ministry of human resources and Social Security issued 
a document "the Interim Measures for the evaluation and supervision of professional titles of teachers in Colleges and universities". This document provided clear guidance opinions on the evaluation of the title from the system to the implementation of the review work.

Since the decentralization of the title evaluation, colleges and universities have completed and formulated the evaluation system of professional titles, in which the supervision mechanism is an important part. After the title assessment rights fall to universities, universities have autonomy, which is not only benefit to the freely development of schools, but also the risk of losing control of supervision. So we should formulate the internal supervision methods in schools under the guidance of the above document.

To strengthen supervision, we must clarify the job responsibilities of all kinds of related persons at all levels. Clear responsibilities and rights are helpful to form a good atmosphere for mutual supervision. Clarifying clear responsibilities of the superior department, the college and the Professional Title Management Department of colleges and universities can ensure the fairness of the program. Clarifying clear responsibilities of various posts and standardizing the procedures can achieve substantial fairness. We can see different hierarchy's responsibilities in Table ц.

TABLE II. DIFFERENT HIERARCHY'S RESPONSIBILITIES

\begin{tabular}{|c|c|c|}
\hline & $\begin{array}{l}\text { Functional } \\
\text { Department }\end{array}$ & $\begin{array}{l}\text { Responsibilities and } \\
\text { Supervision }\end{array}$ \\
\hline \multirow{2}{*}{$\begin{array}{l}\text { External } \\
\text { supervision } \\
\text { department }\end{array}$} & $\begin{array}{c}\text { Human Resources } \\
\text { and social security } \\
\text { department }\end{array}$ & $\begin{array}{l}\text { Title document, review process } \\
\text { supervision and evaluation result } \\
\text { approval; System and procedure } \\
\text { supervision }\end{array}$ \\
\hline & $\begin{array}{l}\text { Bureau of } \\
\text { education }\end{array}$ & $\begin{array}{l}\text { Examination of title documents and } \\
\text { evaluation results; System and } \\
\text { procedure supervision }\end{array}$ \\
\hline \multirow{4}{*}{$\begin{array}{l}\text { School internal } \\
\text { supervision } \\
\text { department }\end{array}$} & $\begin{array}{l}\begin{array}{c}\text { Supervision } \\
\text { department }\end{array} \\
\end{array}$ & Supervision and evaluation work \\
\hline & $\begin{array}{c}\text { Human resources } \\
\text { department }\end{array}$ & $\begin{array}{c}\text { Management and organizer of } \\
\text { professional title assessment; Check } \\
\text { the results of various functional } \\
\text { departments }\end{array}$ \\
\hline & $\begin{array}{l}\text { Other functional } \\
\text { department }\end{array}$ & $\begin{array}{l}\text { Qualification examination materials } \\
\text { and qualification examination; } \\
\text { According to the assessment method, } \\
\text { the applicant's application materials } \\
\text { are audited }\end{array}$ \\
\hline & $\begin{array}{l}\text { Grass-roots } \\
\text { units(School) }\end{array}$ & $\begin{array}{l}\text { The audit of the evaluation materials } \\
\text { for the title of the Department and } \\
\text { the preliminary assessment of the } \\
\text { academic level }\end{array}$ \\
\hline
\end{tabular}

The title evaluation in GDUFE needs to be publicized three times for ensuring the fairness and openness. The first one is in the school of applicants, which will check the applicants 'qualities. The second one is before reviewing. After all the administrative departments and qualification check group have checked the applicants' materials, they will publicize these materials in the university. The last one is the evaluation result publicization. After the evaluation committee completes the review, the administrative department will publicize the person who has passed the review in the whole university.
The procedure of professional title assessment is standardized, and the title work has been completed in good order, which has achieved good evaluation results. However, there are still shortcomings. Due to the lack of clear job responsibilities at various levels, a few colleges have failed to accurately grasp the qualification conditions and relevant policies, and the audit materials are not detailed enough, and some of the declared applicants are not in conformity with the declaration conditions.

\section{Establishing the position duties and assessing strictly}

After the decentralization of the power of assessment, the title reform has achieved some results in different province. Various colleges and universities at all levels have formulated a title system to serve their own development. The combination of evaluation and appointment is the core of the professional title reform. The perfect professional title evaluation system must be consolidated by the corresponding system of post appointment. We should formulate the responsibilities of various posts at all levels, sign job appointment contracts, and strictly implement the assessment mechanism.

GDUFE has formulated the preliminary draft of post setting and personnel employment management methods according to the needs of school personnel training, scientific research, social services and school career development to promote the growth and development of talents (See Table щ). At present, there is no clear post responsibility. If the system is not clear and the assessment system is imperfect, there may be a phenomenon that the implementation of the system is not in place, which to a certain extent affects the fairness of the system.

TABLE III. DIFFERENT POST CLASSIFICATION

\begin{tabular}{|c|c|c|c|}
\hline & \multicolumn{3}{|c|}{ Hierarchy } \\
\hline $\begin{array}{c}\text { Professional } \\
\text { technical } \\
\text { post }\end{array}$ & $\begin{array}{c}\text { Senior } \\
\text { professional } \\
\text { title: teaching } \\
\text { and research } \\
\text { leader, } \\
\text { responsible for } \\
\text { team building } \\
\end{array}$ & $\begin{array}{l}\text { Deputy senior } \\
\text { professional title: the } \\
\text { backbone of teaching } \\
\text { and scientific research }\end{array}$ & $\begin{array}{l}\text { Intermediate } \\
\text { professional } \\
\text { title and below: } \\
\text { reserve forces } \\
\text { for teaching and } \\
\text { research }\end{array}$ \\
\hline $\begin{array}{c}\text { Management } \\
\text { post }\end{array}$ & $\begin{array}{c}\text { School } \\
\text { leaders: } \\
\text { policy-makers }\end{array}$ & $\begin{array}{l}\text { Unit leader (teaching } \\
\text { unit, administrative } \\
\text { unit): responsible } \\
\text { person, planning / } \\
\text { implementing / } \\
\text { supervising and } \\
\text { decision maker }\end{array}$ & $\begin{array}{l}\text { Section level } \\
\text { cadres (chief, } \\
\text { deputy chief } \\
\text { and staff): } \\
\text { executors of } \\
\text { concrete work }\end{array}$ \\
\hline $\begin{array}{c}\text { Teaching } \\
\text { assisting post }\end{array}$ & $\begin{array}{c}\text { School } \\
\text { leaders: } \\
\text { policy-makers }\end{array}$ & $\begin{array}{l}\text { Head of the unit: (in } \\
\text { charge, to provide } \\
\text { high-level services and } \\
\text { technical support for } \\
\text { school development, } \\
\text { teaching and scientific } \\
\text { research work to do a } \\
\text { good job in planning / } \\
\text { implementation / } \\
\text { supervision and } \\
\text { decision-maker) }\end{array}$ & $\begin{array}{c}\text { Teaching } \\
\text { assistants :the } \\
\text { implementers of } \\
\text { service }\end{array}$ \\
\hline
\end{tabular}




\section{CONCLUSION}

The reform of professional titles is an important part of the reform of personnel system in the new era. To achieve an ideal effect, the reform of professional titles should be combined with other parts of the personnel system. The system of professional titles evaluation is the baton for the development and training of teachers. It can arouse the enthusiasm of teachers to play a leading role in the development of schools. Comprehensive and effective supervision service is the guarantee mechanism for the effectiveness of the title system reform; perfecting the post responsibility and implementing the assessment mechanism are the application value of the title system reform results. To further explore how to improve the reform of personnel system and form a good mutually reinforcing and mutually restricting personnel management system is not only the development needs of the new era, but also the core work of giving full play to human resources.

\section{ACKNOWLEDGMENT}

This work was supported by "Research on the classification and evaluation of professional titles in Local Universities under the background of 'Some opinions on deepening to streamline government functions and administration, delegate powers while improving regulation for higher education' " -- the Project of Educational commission of Guangdong province of China(no.2017GXJK053)

\section{REFERENCES}

[1] Ministry of Education. Some Opinions on Deepening the Reform of Simplified Administration, Decentralization and Management in the Field of Higher Education and Optimizing Services (Education and Administration Law [2017] 7) 2017 .03.31(In Chinese).

[2] Huang Yunqing. People's nature is the essential characteristic of socialist university [N].Guangming Daily, 2018.05.11 (06 edition) (In Chinese).

[3] Wang Jianhua. A Research on Current Situations of College Teachers' Academic Rank Assessment and Engagement and Solutions [J].Teacher education research. 2013, 25(5):20-24(In Chinese).

Huang Mei. Analysis of Problems and Related Paths of Chinese Professional Titles System Reform-Based on the Investigation on Status of Professional Titles in 2013[J]. Chinese Public Admin istration. 2015(11) (In Chinese).

[4] Zhu ji. On the Disadvantages and Perfection of the Assessment Procedure on the Title of a Technical or Professional Post of College Teacher of China[J].Journal of Central South University of Forestry \& Technology(Social Sciences). 2011,05 (2):132-134(In Chinese).

[5] Yu Xinglong. On building a professional title evaluation system based on equity [J]. Chinese public administration.2011(11):77-80(In Chinese)

[6] Dong Ning. Research on the status and system design of University Teachers' Professional Title Evaluation in China [D]. Yangzhou University, 2013(In Chinese).

[7] Yang Li. Discussion on the Countermeasures of Advancing Professional Title System Reformation[J]. Chinese Agricultural Science Bulletin. 2013,29(32):209-212(In Chinese).

[8] Chen xiaoqiang. Teachers' recognition of "double teachers and dual abilities" in Independent Colleges under the background of transformation [J]. University Education. 2017(10):177-179(In Chinese).

[9] Huang haibo. The Scientization of Teachers' Performance Appraisal Index Systemin Colleges and Universities: Focusing on Colleges and Universities' Internal Balanced Development [J].Journal of Guangxi Normal University: Philosophy and Social Sciences Edition.2017,53 (2):115-120(In Chinese).

[10] Yin Chengxiang. Cognitive best worst method and its application in professional title evaluation [J]. Journal of PLA University of Science and Technology Natural Science Edition:1-7(2017.09.19) (In Chinese)

[11] Zhang ning. Experience and Enlightenment of teaching staff

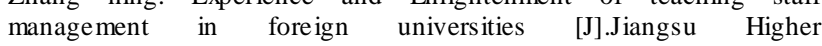
Education,2013,38(5):411-425(In Chinese).

[12] Gardner S K. "Putting in your time": Faculty Experiences in the Process of Promotion to Professor [J]. Innovative Higher Education, 2013, 38(5):411-425. 